\title{
PERAN ESTROGEN PADA REMODELING TULANG
}

\author{
Iknes Sihombing \\ Sunny Wangko \\ Sonny J. R. Kalangi
}

\author{
Bagian Anatomi-Histologi Fakultas Kedokteran Universitas Sam Ratulangi Manado \\ Email: iknessihombing@yahoo.co.id
}

\begin{abstract}
Bone tissues experience continual regeneration of their extracellular components by overhauling the old components. This process is called bone remodeling, which involves several kinds of bone cells. The most important bone cells related to the bone remodeling are osteoblasts, osteocytes, and osteoclats. The bone remodeling is influenced by estrogen. This hormone inhibits bone resorption, resulting in slowing down the osteoporosis process. This antiresorptive effect can be provided also by the estrogen action on osteoblasts, which indirectly influences osteoclast activities. Estrogen has been proved to slow down the decrease of bone mass and fracture risks in women with osteoporosis. Hormone replacement therapy, aimed at replacing estrogen deficiency, consists of phytoestrogen and progesteron; besides that, calcium and vitamine $\mathrm{D}$ are needed, too.
\end{abstract}

Keywords: estrogen, bone remodeling, osteoblast, osteocyte, osteoclast.

\begin{abstract}
Abstrak: Tulang merupakan jaringan yang terus menerus melakukan regenerasi komponenkomponen ekstrasel dengan cara menghancurkan komponen tulang yang sudah tua dan menggantikannya dengan yang baru. Proses ini disebut remodeling tulang, yang melibatkan kerja sel-sel tulang tertentu. Sel-sel dalam tulang yang terutama berhubungan dengan pembentukan dan resorpsi tulang ialah osteoblas, osteosit, dan osteoklas. Remodeling tulang dipengaruhi oleh hormon estrogen. Hormon ini menekan resorpsi tulang sehingga dapat menghambat proses kerapuhan tulang. Efek antiresorptif tersebut dapat pula dihasilkan melalui kerjanya pada osteoblas, yang secara tidak langsung mempengaruhi aktivitas osteoklas. Estrogen terbukti dapat mengurangi laju penurunan massa tulang dan risiko fraktur pada wanita dengan osteoporosis. Terapi sulih hormon yang digunakan untuk mengganti defisisensi estrogen ialah fitoestrogen, progesteron, selain itu juga kalsium dan vitamin D.
\end{abstract}

Kata kunci: estrogen, remodeling tulang, osteoblas, osteosit, osteoklas.

Tulang merupakan jaringan dinamis yang memiliki sistem regenerasi seluler yang kompleks. Sel-sel lama dirombak untuk kemudian diganti dengan sel-sel baru. Keseimbangan dalam resorpsi dan formasi tulang tersebut menentukan densitasnya dan memengaruhi kerentanan seseorang terhadap fraktur. ${ }^{1,2}$

Osteoporosis merupakan salah satu gangguan degeneratif yang ditandai oleh penurunan massa tulang akibat ketidakseimbangan antara resorpsi dan formasi tu- lang. Dua faktor penting yang memberi kontribusi terhadap gangguan ini adalah faktor penuaan dan menurunnya fungsi gonad. Bukti-bukti yang kuat menunjukkan bahwa menurunnya fungsi gonad, terutama sekresi estrogen pada perempuan menopaus, berakibat pada meningkatnya laju resorpsi tulang. ${ }^{1,3}$

Agen yang paling berpengaruh dalam menjaga keseimbangan remodeling tulang tersebut ialah hormon estrogen. Estrogen telah lama dikenal sebagai agen anti- 
resorptif yang bekerja terutama dengan menghambat resorpsi tulang oleh osteoklas. Studi-studi terakhir membuktikan bahwa efek antiresorptif tersebut dapat pula dihasilkan melalui kerjanya pada osteoblas yang secara tidak langsung memengaruhi aktivitas osteoklastik. ${ }^{4,5}$ Suplementasi estrogen terbukti dapat mengurangi laju penurunan massa tulang dan risiko fraktur pada perempuan dengan osteoporosis. ${ }^{4,6}$

\section{HISTOLOGI TULANG}

Tulang merupakan bentuk kaku jaringan ikat yang membentuk sebagian besar kerangka vertebrata yang lebih tinggi. Jaringan ini terdiri atas sel-sel dan matriks intersel. Matriks mengandung unsur organik, yaitu terutama serat-serat kolagen, dan unsur anorganik yang merupakan dua pertiga berat tulang itu. Garam-garam anorganik yang bertanggungjawab atas kaku dan kejurnya tulang ialah kalsium fosfat (kira-kira 85\%), kalsium karbonat (10\%), dan sejumlah kecil kalsium florida serta magnesium florida. Serat-serat kolagen sangat menambah kekuatan tulang itu.

\section{Struktur tulang}

Secara makroskopik, tulang dapat dibedakan menjadi dua macam: tulang spongiosa dan tulang kompakta. Tulang kompakta terdiri dari sistem-sistem Harvesian atau osteon yang tersusun padat. Sistem Harvesian terdiri dari sebuah saluran pada bagian tengahnya (kanal Harvesian) yang dikelilingi oleh cincin-cincin konsentris (lamela) di sela-sela matriks. Sel-sel tulang (osteosit) berada pada lakuna di antara lamelae. Lakuna berhubungan secara langsung dengan kanal Harvesian melalui saluran kecil yang disebut kanalikuli. Pembuluh darah tulang berada di dalam kanal Harvesian dan tersusun paralel terhadap aksis longitudinal tulang. Tulang spongiosa yang lebih ringan dan tidak sepadat tulang kompakta tersusun dari lempengan trabekula yang dihubungkan oleh kanalikuli dengan ruang-ruang kecil ireguler berisi sumsum tulang yang disebut kavitas. Trabekula dan kavitas memang tersusun longgar dan tidak beraturan, namun struktur seperti ini justru berfungsi memaksimalkan kekuatan tulang. Struktur ini tidak kaku dan dapat menyesuaikan diri dengan tekanan fisik pada tulang (Gambar 1 dan 2). ${ }^{7-9}$

\section{Sel-sel tulang}

Tulang dewasa dan yang sedang berkembang mengandung empat jenis sel berbeda: sel osteogenik (osteoprogenitor), osteoblas, osteosit, dan osteoklas (Gambar 3). ${ }^{7,10}$ Sel-sel osteogenik ialah sel-sel induk pluripoten yang belum berdiferensiasi, berasal dari jaringan ikat mesenkim. Sel ini biasanya ditemukan pada permukaan tulang di lapisan dalam periosteum, pada endosteum, dan dalam saluran vaskular dari tulang kompakta. Terdapat dua jenis sel osteoprogenitor: 1) preosteoblas yang memiliki sedikit retikulum endoplasma dan akan menghasilkan osteoblas; dan 2) preosteoklas yang mengandung lebih banyak mitokondria dan ribosom bebas, dan menghasilkan osteoklas. ${ }^{7}$

Osteoblas membuat, menyekresikan, dan mengendapkan unsur organik matriks tulang baru yang disebut osteoid. Osteoblas mengandung enzim fosfatase alkali yang menandakan bahwa sel-sel ini tidak hanya berhubungan dengan pembuatan matriks, namun juga mineralisasinya. Osteoid ialah matriks tulang belum mengapur, baru dibentuk, dan tidak mengandung mineral, namun tidak lama setelah deposisi, osteoid segara mengalami mineralisasi dan menjadi tulang. ${ }^{7}$

Osteosit atau sel tulang ialah osteoblas yang terpendam dalam matriks tulang. Mikroskop elektron memperlihatkan bahwa osteosit dan cabangnya tidak melekat lang sung pada matriks sekitarnya, tetapi terpisah dari dinding lakuna dan kanalikuli oleh daerah amorf tipis. Daerah ini agaknya berfungsi sebagai medium pertukaran metabolit.?

Osteoklas ialah sel multinuklear besar yang terdapat di sepanjang permukaan tulang tempat terjadinya resorpsi, remodeling, dan perbaikan tulang. Osteoklas ini sering terdapat di dalam sebuah lekuk dangkal pada tulang yang teresorpsi atau 


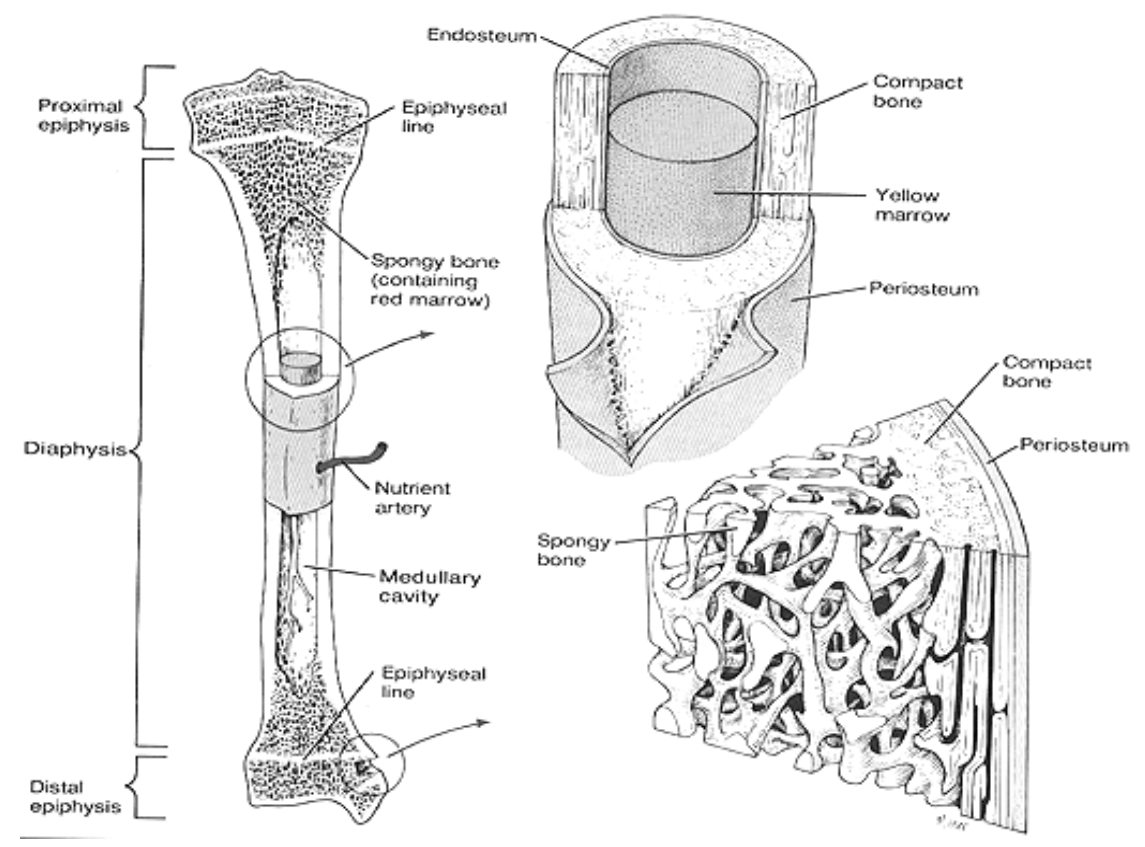

Gambar 1. Beda tulang kompakta dan spongiosa pada sebuah tulang panjang. Bagian kiri mengilustrasikan pembagian tulang panjang berdasarkan aksis longitudinalnya. Bagian kanan mengilustrasikan perbedaan antara tulang kompakta dan tulang spongiosa. Sumber: Spence, $1990 .^{9}$

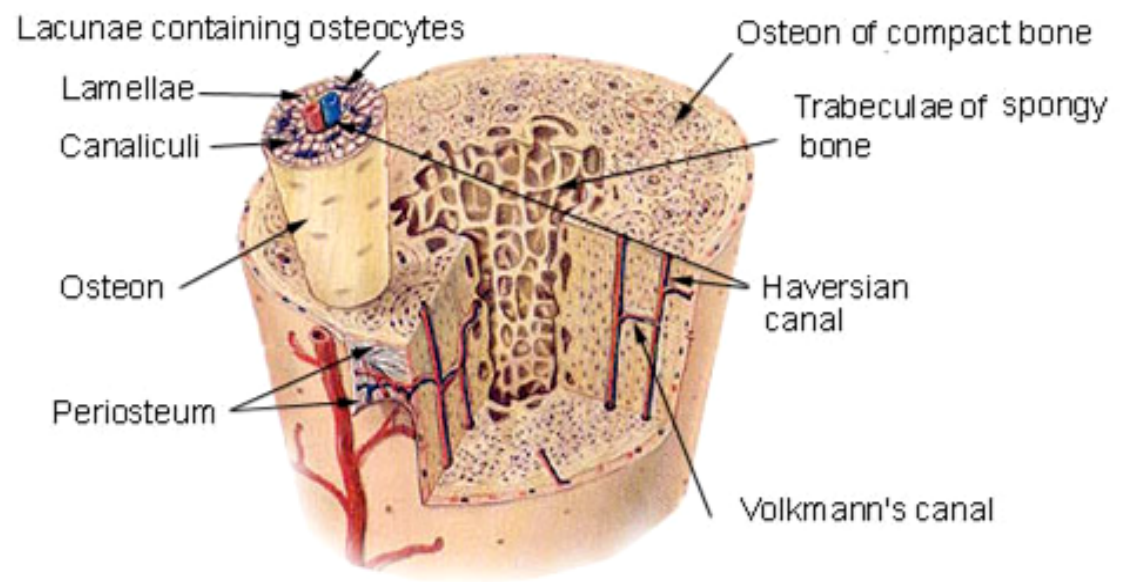

Gambar 2. Penampang melintang tulang matur. Tulang kompakta tersusun lebih padat, berada di pinggiran tulang. Tulang spongiosa lebih longgar dengan trabekula ireguler dan berada dekat sumsum tulang. Sumber: anonim.

terkikis secara enzimatik yang disebut lakuna Howship. Osteoklas yang mula-mula berada di dalam tulang berasal dari prekursor mirip monosit. Sel-sel ini terlibat mengeluarkan kolagenase dan enzim proteolitik lain yang menyebabkan matriks tulang melepaskan bagian substansi dasar yang mengapur. Sesudah proses resorpsi rampung, osteoklas menghilang, mungkin berdegenerasi atau berubah lagi menjadi sel asalnya. $^{7}$

Osteoblas dan osteoklas diproduksi pada sumsum tulang dan terbentuk melalui dua garis diferensiasi CFU (colony formation unit) yang berbeda. Pembentukan osteoklas dari CFU-GM (granulosit-makrofag) 


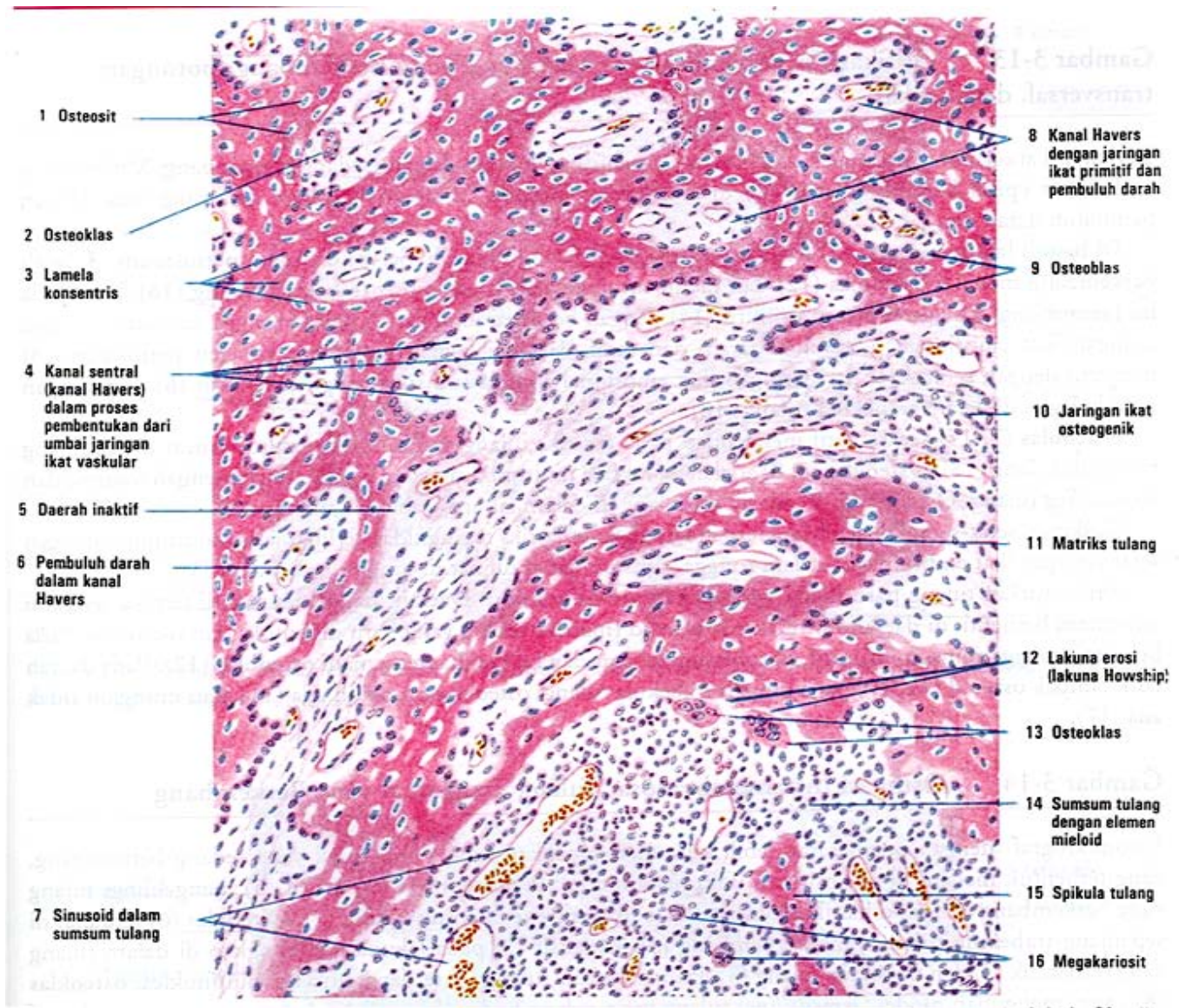

Gambar 3. Penampang longitudinal unit pertumbuhan tulang yang memperlihatkan distribusi osteosit, osteoblas, dan osteoklas. Sumber: Di Fiore, $2003 .^{10}$

mengikuti garis diferensiasi hematopoietik, sedangkan pembentukan osteoblas dari CFU-F (fibrosit) mengikuti garis diferensiasi mesensimal pada stroma sumsum tulang (Gambar 4). Pembentukan osteoblas dapat berlangsung secara independen tanpa memerlukan interaksi dengan progenitor osteoklas. Sebaliknya, pembentukan osteoklas membutuhkan interaksi yang kompleks dengan progenitor osteoblas, dimana diferensiasi CFU-GM menjadi osteoklas tidak dapat berlangsung tanpa adanya interaksi seluler komponen sel-sel stroma yang memproduksi osteoblas (Gambar 5). 1,2,11

\section{Matriks tulang}

Matriks tulang secara khas tersusun dalam lapisan-lapisan atau lamel-lamel setebal 3-7 mm. Lamel-lamel itu merupakan hasil peletakan matriks yang terjadi secara ritmik. Serat dalam lamel teratur sejajar satu terhadap lainnya dalam bentuk pilinan atau heliks. Puncak pilinan beralih dalam lamel sebelahnya dengan sudut $90^{0}$.

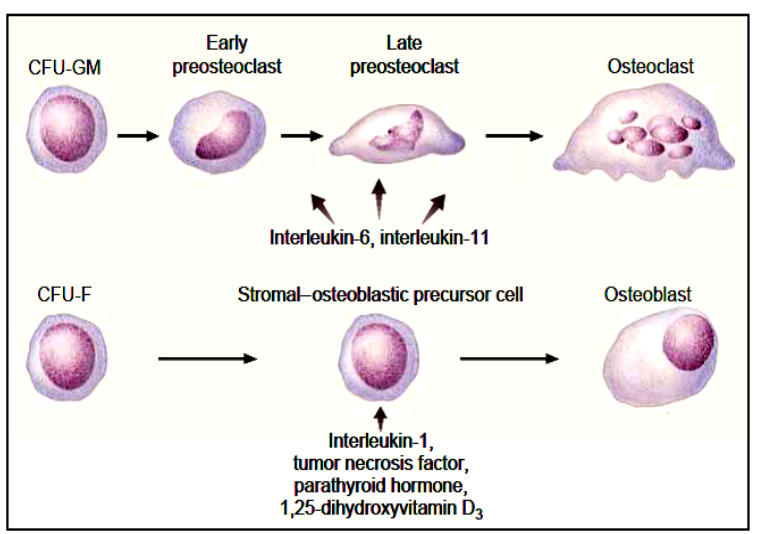

Gambar 4. Perbedaan antara garis diferensiasi osteoklas dan osteoblas. Garis diferensiasi hematopoietik (atas) bertanggungjawab dalam pembentukan osteoklas, sedangkan osteoblas terbentuk melalui garis diferensiasi mesensimal (bawah). Keduanya dimediasi oleh sejumlah sitokin dan hormon yang berbeda. Sumber: Epstein, $1995 .{ }^{1}$ 


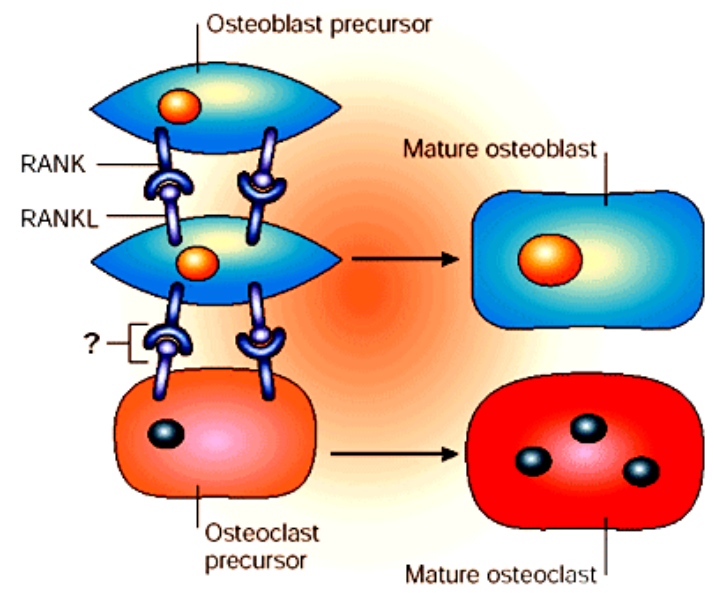

Gambar 5. Ketergantungan terhadap osteoblas dalam diferensiasi osteoklas. Pembentukan osteoklas matur mutlak memerlukan interaksi dengan prekursor osteoblas melalui interaksi RANK dengan ligannya (RANKL). Sumber: Teitelbaum et al, 2003. ${ }^{12}$

Susunan serat yang berselang-seling demikian menjelaskan mengapa lamel terlihat begitu jelas. Serat kolagen dalam satu lamel akan tampak sebagai bangunan memanjang, pada yang sebelah serat itu ter- potong melintang dan tampak granular. Unsur organiknya mencakup kira-kira 35\%, terutama terdiri dari serat-serat osteokolagen serupa dengan serat kolagen tipe I jaringan ikat longgar. Unsur anorganik terutama terdapat di bagian semen di antara serat-serat dan merupakan 65\% dari berat tulang. Mineral terutama terdapat berupa kristal kalsium fosfat dalam bentuk yang serupa dengan hidroksiapatit. ${ }^{7}$

\section{REMODELING TULANG}

\section{Peran osteoblas dan osteoklas dalam re- modeling tulang}

Proses remodeling merupakan dua tahapan aktivitas seluler yang terjadi secara siklik, yakni resorpsi tulang lama oleh osteoklas dan formasi tulang baru oleh osteoblas. Pertama-tama, osteoklas akan menyelenggarakan resorpsi melalui proses asidifikasi dan digesti proteolitik. Segera setelah osteoklas meninggalkan daerah resorpsi, osteoblas menginvasi area tersebut dan memulai proses formasi dengan cara menyekresi osteoid (matriks kolagen dan protein lain) yang kemudian mengalami mineralisasi (Gambar 6).

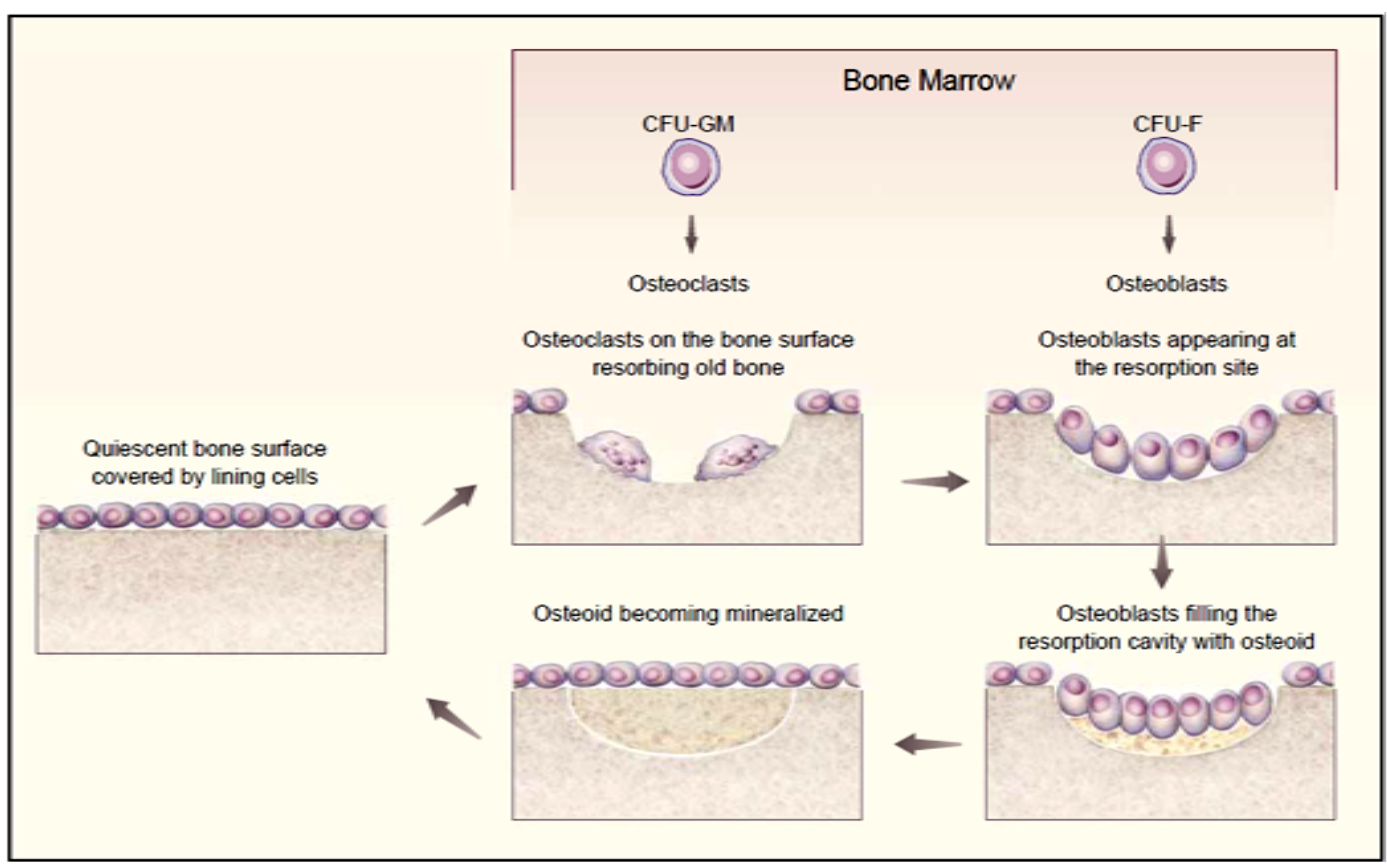

Gambar 6. Skema proses remodeling tulang. Dalam siklus ini, aktivitas yang konstan dalam diferensiasi osteoblas dan osteoklas dari sel-sel progenitornya merupakan tahap esensial dalam menjaga keseimbangan antara resorpsi tulang lama dan formasi tulang baru. Sumber: Epstein, $1995 .{ }^{1}$ 
Normalnya, kecepatan resorpsi dan formasi tulang berlangsung dalam kecepatan yang sama sehingga massa tulang tetap konstan. ${ }^{1,2,11}$

\section{Faktor-faktor yang mempengaruhi re- modeling tulang}

Aktivitas resorpsi dan formasi tulang diregulasi oleh berbagai faktor sistemik yang kompleks. Keseimbangan antara aktivitas osteoklastik dan osteblastik dijaga oleh pasokan hormon steroid yang konstan pada sel-sel tulang. Gangguan dalam regulasi tersebut nampak jelas pada penuaan dan keadaan defisiensi hormon estrogen. ${ }^{1,13}$ Selain itu usia dan keadaan menopause, faktor-faktor risiko yang juga dikenal mempengaruhi massa dan densitas tulang antara lain densitas tulang awal (yang dibawa ketika lahir) dan ketersediaan kalsium. ${ }^{3}$

Faktor lain yang berperan dalam regulasi remodeling tulang ialah vitamin $\mathrm{D}$, dimana suplementasi vitamin D terbukti dapat meningkatkan kepadatan tulang, bahkan pada wanita menopause sekalipun. ${ }^{14}$ Hormon paratiroid dapat meningkatkan resorpsi tulang dengan cara melepaskan kalsium dari matriks tulang ke dalam sirkulasi darah untuk menjaga kadar kalsium darah agar tetap normal. ${ }^{15}$ Regulator lain ialah hormon paratiroid serta berbagai sitokin dan enzim yang berperan sebagai koregulator maupun koreseptor dalam diferensiasi maupun aktivitas sel-sel tulang. ${ }^{13}$

\section{Osteoporosis dan gangguan lain dalam remodeling tulang}

Osteoporosis merupakan keadaan berkurangnya massa tulang akibat ketidakseimbangan resorpsi dan formasi tulang yang bisa bersifat fisiologik maupun patologik. Jumlah formasi tulang baru akan berkurang seiring dengan bertambahnya usia karena menurunnya pasokan osteoblas yang tidak bisa mengimbangi kecepatan resorpsinya. Penurunan massa tulang akibat penuaan mulai terjadi pada dekade 4-5 kehidupan dengan kecepatan 0,3 - 0,5\% per tahun. Berbeda dengan osteoporosis pada penuaan yang lebih disebabkan oleh me- nurunnya pasokan osteoblas, osteoporosis pada defisiensi estrogen cenderung dikaitkan dengan peningkatan aktivitas osteoklastik. Laju penurunan massa tulang dapat bertambah hingga 10 kali lipat pada wanita menopause atau pria yang telah menjalani vasektomi. ${ }^{1,13}$

Osteopetrosis merupakan contoh gangguan remodeling tulang lainnya. Gangguan herediter ini ditandai oleh defek pada aktivitas resorpsi tulang yang diperankan oleh osteoklas, sedangkan formasi tulang oleh osteoblas tetap berlangsung seperti biasa. Akibatnya terjadi peningkatan massa tulang akibat meningkatnya massa tulang. Pemeriksaan radiologik menunjukkan gambaran "tulang di dalam tulang" dan pembesaran ukuran tulang. ${ }^{2}$

\section{PERAN ESTROGEN DALAM REMO- DELING TULANG}

\section{Hormon estrogen dan reseptornya}

Estrogen endogen yang banyak ditemukan dalam tubuh manusia adalah estradiol-17ß $\left(E_{2}\right)$, estron $\left(E_{1}\right)$ dan estriol $\left(E_{3}\right)$. Ketiganya merupakan steroid dengan 18 atom karbon yang terbentuk dari kolesterol. ${ }^{4}$

Sumber primer estradiol ialah kelenjar gonad (sel teka dan sel granulosa ovarium pada perempuan dan sel Leydig pada lakilaki), sedangkan estron dan estriol disintesis di hepar dari estradiol. Selain itu, pembentukan senyawa estrogen dapat pula berlangsung di otot, jaringan lemak, jaringan saraf dan trofoblas. ${ }^{4}$

Efek estrogen hanya terlihat pada selsel dan jaringan yang memiliki reseptor estrogen. Fungsi estrogen dalam tubuh manusia ditentukan oleh jenis reseptor estrogen, lokasi reseptor dan interaksinya antara estrogen, reseptornya dan struktur lain di dalam sel target. Sejauh ini dikenal dua jenis reseptor estrogen: reseptor alfa $(\mathrm{ER} \alpha)$ dan reseptor beta (ER $\beta)$. Meskipun ER $\alpha$ dan ER $\beta$ berinteraksi dengan ligan estrogen yang sama, yakni estradiol-17ß, keduanya memiliki perilaku yang berbeda, bahkan bertentangan. Sebagai contoh, ER $\alpha$ yang terikat dengan ligan dapat mengaktivasi 


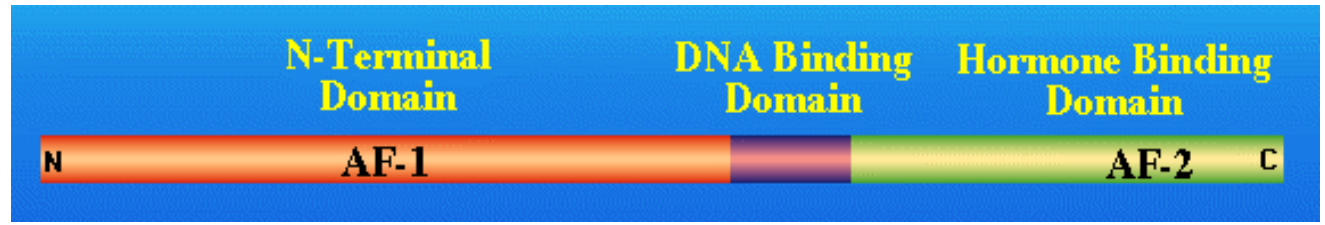

Gambar 7. Domain-domain fungsional pada sebuah reseptor estrogen. Sumber: McDowall, 2003. ${ }^{16}$

transkripsi gen, sedangkan ER $\beta$ justru menginhibisi transkripsi. ${ }^{16}$

ER $\alpha$ dan ER $\beta$ memiliki struktur fisik yang terbagi atas beberapa domain fungsional (Gambar 7): domain transaktivasi terminal-N (NTD), domain pengikat DNA (DBD), dan domain transaktivasi terminal$\mathrm{C}$ yang merupakan domain pengikat ligan estrogen (HBD). Setiap domain memiliki fungsi tersendiri dalam interaksi reseptor dengan ligan dan interaksi dengan DNA pada saat domain tersebut menggiatkan atau menghambat transkripsi genetik. ${ }^{4,16}$

Efek biologik estrogen dimulai ketika estrogen (sebagai ligan) berdifusi ke dalam sel lalu berikatan dengan domain pengikat ligan HBD. Sebelum mengikat ligan, reseptor estrogen berada dalam keadaan inaktif di dalam nukleus atau sitoplasma sel dan terikat dengan protein tertentu yang disebut receptor-associated protein (RAP). RAP terikat pada domain pengikat DNA (DBD) dan berfungsi sebagai saperon (chaperone) yang menstabilkan struktur reseptor sebelum ia teraktivasi. Saat berikatan dengan ligan dan terlepas dari RAP, reseptor akan teraktivasi dan terbentuklah kompleks estrogen-reseptor yang mampu menembus masuk ke nukleus (translokasi) apabila ia masih berada dalam sitoplasma. Kompleks estrogen-reseptor ini akan berikatan dengan bagian tertentu pada DNA yang disebut estrogen-response-element (ERE). Proses ini berlanjut sebagai transkripsi genetik yang kompleks yang menentukan efek biologis estrogen di dalam sel bersangkutan (Gambar 8). ${ }^{4,16}$

Mekanisme tersebut memperlihatkan jalur klasik aktivasi reseptor estrogen yang membutuhkan adanya hormon estrogen sebagai ligan. Jalur klasik ini disebut liganddependent receptor activation. Aktivasi reseptor dapat pula terjadi melalui jalur-

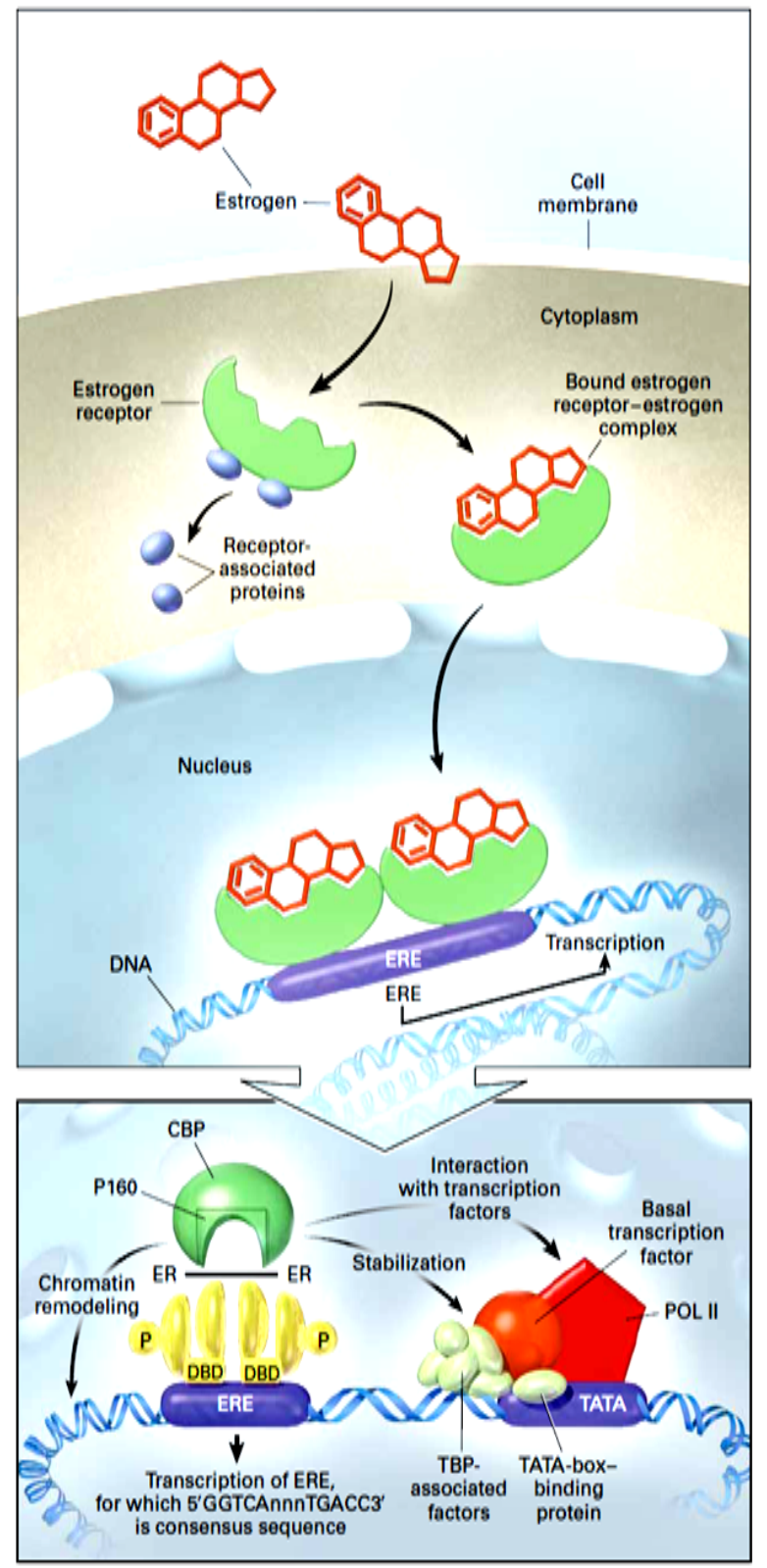

Gambar 8. Mekanisme kerja estrogen di dalam sel. Aksi seluler estrogen dimulai dengan masuknya estrogen ke dalam sel, berikatan dengan reseptornya (ER) membentuk kompleks estrogen-reseptor yang langsung bertranslokasi ke dalam nukleus. Di nukleus, kompleks ini berikatan dengan estrogen-response-element, bagian tertentu pada DNA, yang memperantarai transkripsi genetik dan efek biologik estrogen. Sumber: Grubber et al, 2002. ${ }^{4}$ 
jalur alternatif tanpa melibatkan terbentuknya kompleks estrogen-reseptor atau ketika interaksi estrogen-reseptor terjadi di luar sel (Gambar 9). Jalur alternatif pertama, ligand-independent receptor activation, terjadi ketika estrogen mengaktifkan growth factor yang merupakan aktivator terhadap protein kinase. Reseptor estrogen yang sebagian besar merupakan fosfoprotein dapat mengalami aktivasi independen akibat meningkatnya kadar protein kinase intrasel yang menyebabkan perubahan dalam fosforilasinya. Kedua jalur tersebut melibatkan translokasi atau masuknya reseptor ke dalam nukleus yang membutuhkan waktu beberapa menit hingga berjamjam. Kenyataanya, efek estrogen pada sebuah sel tunggal dapat terjadi lebih cepat dari itu; diduga karena mekanisme ekstranuklear melalui pembentukan kompleks estrogen-reseptor di membran sel yang menyebabkan efek biologis non-transkripsional yang diperantarai protein kinase. ${ }^{4}$

\section{Efek estrogen pada sel-sel tulang}

Reseptor estrogen dapat ditemukan pada sel osteoklas maupun osteoblas. ${ }^{4,17}$ Estrogen telah lama dikenal sebagai agen antiresorptif yang bekerja terutama dengan menekan aktivitas osteoklastik., ${ }^{4,5}$ Namun studi-studi terakhir membuktikan bahwa efek antiresorptif tersebut dapat pula dihasilkan melalui kerjanya pada osteoblas yang secara tidak langsung mempengaruhi aktivitas osteoklastik. ${ }^{4}$

\section{Efek estrogen pada aktivitas osteoklas}

Shevde et $\mathrm{al}^{18}$ membuktikan bahwa estrogen bekerja dengan menekan diferensiasi osteoklas. Sebelumnya telah dijelaskan (Gambar 6) bahwa pembentukan osteoklas memerlukan interaksi antara RANK (receptor activator nuclear factor kappa $B$, NF-кB) dan ligannya, RANKL. Interaksi antara RANK dan RANKL ini diregulasi oleh produksi osteoprotegerin (OPG). Estrogen mengendalikan diferensiasi osteoklas dengan cara menghambat interaksi antara RANK dan RANKL. Estrogen pun dapat menghambat produksi IL-6, IL-1 dan atau TNF- $\alpha$, IL-11, IL-7 dan TGF- $\beta$ yang juga penting dalam diferensiasi osteoklas. $5,11,18$

Lama hidup osteoklas juga menentukan jumlah sel osteoklas pada permukaan resorpsi tulang. Hughes et al. ${ }^{18}$ membuktikan bahwa estrogen dapat menginduksi apoptosis dan kematian osteoklas sehingga dapat secara langsung menurunkan aktivitas resorpsi. ${ }^{18}$

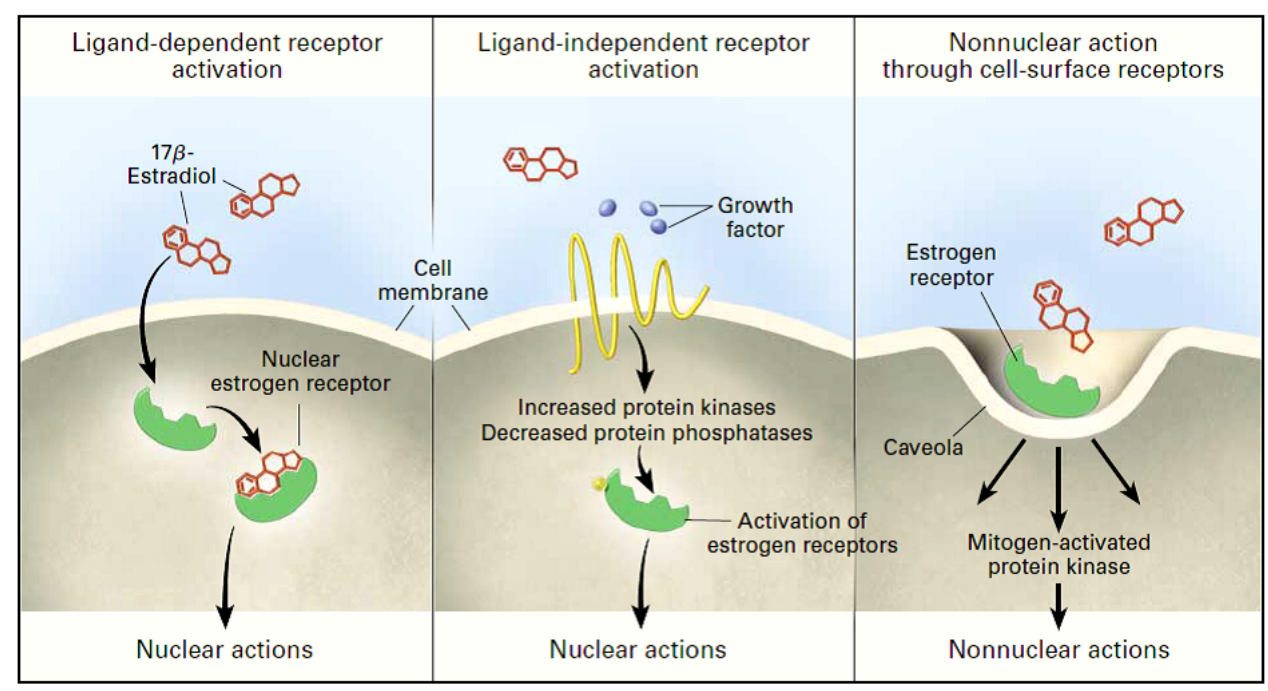

Gambar 9. Tiga jalur aktivitas biologis estrogen pada sel. Selain aktivasi reseptor estrogen yang diikuti oleh translokasi dan transkripsi di dalam nukleus, aktivasi reseptor dapat terjadi pada membran sel di luar sitoplasma, dimana efek biologis estrogen tidak melibatkan transkripsi genetik. Sumber: Grubber et al, 2002. ${ }^{4}$ 


\section{Efek estrogen pada aktivitas osteoblas}

Efek estrogen dalam menekan aktivitas osteoklastik dapat terjadi secara tidak langsung melalui aksinya pada reseptor osteoblastik. Salah satu sitokin yang diproduksi oleh osteoblas, TGF-ß, ditekan produksinya oleh estrogen. TGF-ß berperan dalam diferensiasi osteoklas serta kelangsungan hidupnya. ${ }^{18}$ Estrogen pun menstimulasi produksi OPG (osteoprotegerin) oleh osteoblas. OPG merupakan reseptor TNF yang penting dalam menghambat diferensiasi dan aktivitas osteoklas. ${ }^{17}$ Estrogen juga mengendalikan aktivitas osteoklastik dengan menekan produksi interleukin-6 (IL-6) yang diproduksi osteoblas. ${ }^{19}$

\section{BAHASAN}

Secara normal di tubuh kita terjadi suatu tahapan yang disebut remodeling tulang, yaitu suatu proses pergantian tulang yang sudah tua untuk di ganti dengan tulang yang baru. Hal ini sudah terjadi pada saat pembentukan tulang mulai berlangsung sampai selama kita hidup. Setiap saat terjadi remodeling tulang di tulang manusia. Proses remodeling ini dimulai dengan terjadinya resorpsi atau penyerapan atau penarikan tulang oleh sel tulang yaitu osteoklas, kemudian tulang yang sudah di serap akan diisi oleh tulang yang baru dengan bantuan sel tulang yaitu osteoblas. ${ }^{1,2,11}$

Proses resorpsi oleh osteoklas dan formasi oleh osteoblas dipengaruhi oleh banyak faktor, seperti faktor humoral (sitokin, prostaglandin, faktor pertumbuhan), dan faktor sistemik (kalsitonin, estrogen, kortikosteroid, tiroksin). Sitokin yang meningkatkan kerja osteoklas ialah granulocyte-macrophage colony-stimulating factors (GM-CSF), macrophage colony-stimulating factors (M-CSF), tumor necrosis factor $\alpha$ (TNF- $\alpha$ ), interleukin-1 (IL-1) dan interleukin-6 (IL-6); sedangkan faktor lokal yang meningkatkan kerja osteoblas ialah IL-4, dan transforming growth factor $\beta$ (TGF- $\beta)^{1,3,13,14}$

Estrogen menghambat resorpsi tulang dengan menghambat $\mathrm{PTH}$, menekan produksi IL-1, IL-6 dan TNF $\alpha$, dan menghambat interaksi RANK-RANKL dengan menstimulasi sel stroma menghasilkan OPG. Hal ini menunjukkan betapa pentingnya estrogen replacement therapy pada wanita pasca menopause untuk mencegah terjadinya osteoporosis pasca menopause (post menopause osteoporosis). ${ }^{5,11,18}$

Terapi sulih hormon yang di gunakan saat estrogen menurun ialah fitroestrogen. Fitoestrogen ialah fitokimia yang memiliki aktivitas estrogenik. Terdapat banyak senyawa fitoestrogen, tetapi yang telah diteliti ialah isoflavon dan lignans. Isoflavon yang berefek estrogenik antara lain genistein, daidzein dan gliklosidanya yang banyak ditemukan pada golongan kacang-kacangan (Leguminosae) seperti soy bean dan red clover. Selain fitoestrogen, kalsium dan vitamin D juga bisa menjadi terapi sulih hormon. Kalsium merupakan unsur yang sangat diperlukan tubuh, baik pada masa pertumbuhan maupun pada masa pasca menopause. Pada masa pertumbuhan, pemberian kalsium dengan dosis yang cukup akan mengakibatkan pertumbuhan tulang dapat mencapai maksimal, sedangkan pemberian kalsium pada masa pasca menopause dapat menghambat resorpsi tulang. Vitamin D berperan dalam pembentukan matriks yang bekerja dengan cara menyintesis kolagen tipe I dan osteokalsin namun dapat juga berperan dalam proses remodeling tulang. Vitamin D membantu dalam proses pembentukan osteoklas dan apabila dalam konsentrasi yang sangat banyak dapat merangsang osteoklas meresorpsi tulang. ${ }^{20}$

\section{SIMPULAN}

Tulang merupakan jaringan yang terus menerus melakukan regenerasi komponenkomponen ekstraselnya dengan cara menghancurkan komponen tulang yang sudah tua dan menggantinya dengan yang baru (remodeling) yang melibatkan kerja osteoblas, osteosit, dan osteoklas.

Estrogen memengaruhi resorpsi tulang yaitu menghambat proses kerapuhan tu- 
lang. Terapi sulih hormon berfungsi untuk mengatasi defisiensi estrogen, antara lain dengan menggunakan fitoestrogen, progesteron, kalsium dan vitamin D untuk menghambat osteoporosis.

\section{DAFTAR PUSTAKA}

1. Epstein FH. Bone marrow, cytokines, and bone remodelling. N Engl J Med [serial online]. 1995 Feb 2 [cited 2010 Jan 9]; 332(5):305-11. Available from: URL: http://content.nejm.org/cgi/reprint/332/ 5/305.pdf

2. Tolar J, Teitelbaum SL, Orchard PJ. Osteopetrosis. N Engl J Med [serial online]. 2004 Des 30 [cited 2010 Jan 19]; 351(27):2839-49. Available from: URL: http://content.nejm.org/cgi/re print/351/27/2839.pdf

3. Riggs BL. Pathogenesis of osteoporosis. Am J Obstet Gynecol [serial online]. 1987 Mei [dikunjungi 2009 Nov 17]; 156(5):1342-6. Available from: URL: http://www.ncbi.nlm.nih.gov/pubmed/3 578454

4. Gruber CJ, Tschugguei W, Schneebeger C, Huber JC. Production and action of estrogens. N Engl J Med [serial online]. 2002 Jan 31 [cited 2010 Jan 19]; 346:340-50. Available from: URL: http://content.nejm.org/cgi/reprint/346/ 5/340.pdf

5. Bell NH. RANK ligand and the regulation of skeletal remodeling. J Clin Invest [serial online]. 2003 Apr [dikunjungi 2009 Nov 17];111:1120-2. Available from: URL: http://www.jci.org/articles/ view/18358/pdf.

DOI: 10.1172/JCI200318358

6. Guyton AC, Hall JE. Buku ajar fisiologi kedokteran (Edisi Kesembilan). Jakarta: EGC, 1997; p.1291-2.

7. Leeson CR, Leeson TS, Paparo AA. Buku Ajar Histologi (Edisi Kelima). Jakarta: EGC, 1996; p.138-56.

8. Structure of bone tissue. National Cancer Institute: SEER Training Modules [homepage on the Internet]. Nodate [cited 2009 Nov 17]. Available from: URL: http://training.seer.cancer.gov/ anatomy/skeletal/tissue.html

9. Conrad E. Structure of bone. MAC [homepage on the Internet]. Nodate [diunduh 2009 Nov 17]. Available from: URL: http://homepage.mac.com/ myers/ misc/ bonefiles/bonestruct.html

10. Eroschenko VP. Atlas histology Di Fiore dengan korelasi fungsional (Edisi Kesembilan). Jakarta: EGC, 2003; p.51-2.

11. Bezerra MC, Carvalho JF, Prokopowitsch AS, Pereira RMR. RANK, RANKL and osteoprotegerin in arthritic bone loss. Braz J Med Biol Res [serial online]. 2005 [cited 2009 Nov 17];38(2):161-70. Available from: URL: http://www.scielo.br/pdf/bjmbr/ v38n2/5600.pdf

12. Teitelbaum SL, Ross FP. Teitelbaum LS, Ross PF. Genetic regulation of osteoclast development and function. Nat Rev Gen [serial online]. 2003 Aug 1 [cited 2001 Jan 9];4:638-49. Available from: URL: http://www. nature.com/nrg/journal/v4/n8/fig_tab/nr g1122_F5.html, DOI: 10.1038/nrg1122

13. Monroe DG, Secreto FJ, Spelsberg TC. Overview of estrogen action in osteoblast: role of the ligand, the receptor, and the co-regulators. J Musculoskel Neuron Interact [serial online]. 2003 Agu 1 [cited 2009 Nov 17];3(4):357-62. Available from: URL: http://www.ismni.org/jmni/pdf/14/ 31SPELSBERG.pdf

14. Jackson RD, LaCroix AZ, Gass M, Wallace RB, Robbins J, Lewis CE, et al. Calcium plus vitamin D supplementation and the risk of fractures. N Engl J Med [serial online]. 2006 Feb 16 [dikunjungi 2010 Jan 19];234(7):669-83 Available from: URL: http://content.nejm.org/cgi/ reprint/354/7/669.pdf

15. Grey A, Mitnick M, Masiukiweicz U, Sun B, Rudikoff S, Jilka RL, et al. A role for interleukin-6 in parathyroid hormone-induced bone resorption in vivo. Endo [serial online]. 1999 [cited 2010 Jan 19];140(10):4683-90. Available from: URL: http://endo.endo journals.org/cgi/reprint/140/10/4683

16. McDowall J. Oestrogen receptors. InterPro Protein Acrhives [serial on the Internet]. 2003 [dikunjungi 2009 Nov 17];4 hal. Available from: URL: http://www.ebi.ac.uk/interpro/potm/200 3_4/Page_1.htm

17. Hofbauer LC, Khosla S, Dunstan CR, Lacey CR, Lacey DL, Spelsberg TC, 
S28 Jurnal Biomedik, Volume 4, Nomor 3, Suplemen, November 2012, hlm. S18-28

et al. Estrogen stimulates gene expression and protein production of osteoprotegerin in human osteoblastic cells. Endo [serial online]. 1999 [dikunjungi 2010 Jan 19];140(9:436870. Available from: URL: http://endo. endojournals.org/cgi/reprint/140/9/4367

18. Oursler MJ. Direct and indirect effects of estrogen on osteoclast. J Musculoskel Neuron Interact [serial online]. 2003 Agu 1 [cited 2009 Nov 17];3(4):363-6. Available from: URL: http://www. ismni.org/jmni/pdf/14/32OURSLER.pdf

19. Rifas L, Kenney JS, Marcelli M, Pacifici
R, Cheng SL, Dawson LL, et al. Production of interleukin-6 in human osteoblasts and human bone marrow stromal cells: evidence that induction by interleukin-1 and tumor necrosis factor-alpha is not regulated by ovarian steroids. Endo [serial online]. 1995 [cited 2009 Nov 17];136:4056-67. Available from: URL: http://endo.endo journals.org/cgi/content/abstract/136/9/ 4056

20. Rosevear SK. Handbook of gynaecology management. Oxford: Blackwell Science, 2002; p.32-4. 